\title{
KINERJA MANAJEMEN LALU LINTAS BARU DI KAWASAN LOSARI KOTA MAKASSAR
}

\author{
Qadriathi Dg Bau \\ Teknik Sipil dan Perencanaan \\ Fakultas Teknik \\ Universitas Negeri Makassar \\ Jln. Malengkeri Raya, Makassar \\ qadriathidgbau@gmail.com
}

\author{
Ichsan Ali \\ Teknik Sipil dan Perencanaan \\ Fakultas Teknik \\ Universitas Negeri Makassar \\ Jln. Malengkeri Raya, Makassar
}

\author{
Nurul Tri Ayu Reski \\ Teknik Sipil dan Perencanaan \\ Fakultas Teknik \\ Universitas Negeri Makassar \\ Jln. Malengkeri Raya, Makassar
}

\begin{abstract}
The problem of urban traffic congestion is the main thing that always gets attention because congestion has a negative impact on the economy, the environment, and vehicle drivers. Makassar City is one of the cities experiencing traffic congestion on several existing roads, including roads in the Losari Area. Various efforts have been made by the government to reduce traffic congestion in the area, but optimum results have not been obtained. In 2019, a change in the direction of traffic movement in the Losari area was done by implementing a traffic management called the New Traffic Management. Through this new scheme, changes are made in the direction of movement of traffic on Jalan Penghibur, Jalan Haji Bau, and Jalan Lamadukelleng. This study aims to analyze the performance of the New Traffic Management towards improving traffic conditions in the Losari Area. The results of this study indicate that the application of New Traffic Management in the Losari Area has succeeded in improving traffic conditions in the area. Through this new traffic management scheme, the three road sections observed have service level A.
\end{abstract}

Keywords: traffic congestion, traffic management, service level

\begin{abstract}
Abstrak
Masalah kemacetan lalu lintas di perkotaan merupakan hal utama yang selalu mendapat perhatian karena kemacetan menimbulkan dampak negatif terhadap ekonomi, lingkungan, dan pengemudi kendaraan. Kota Makassar merupakan salah satu kota yang mengalami kemacetan lalu lintas di beberapa ruas jalan yang ada, termasuk jalan-jalan di kawasan Losari. Berbagai upaya telah dilakukan oleh pemerintah untuk mengurangi kemacetan lalu lintas di kawasan tersebut, tetapi belum diperoleh hasil yang optimum. Pada tahun 2019, dilakukan perubahan arah pergerakan lalu lintas di kawasan Losari dengan menerapkan suatu manajemen lalu lintas yang dinamakan Manajemen Lalu Lintas Baru atau New Traffic Management. Melalui skema yang baru ini dilakukan perubahan arah pergerakan lalu lintas di Jalan Penghibur, Jalan Haji Bau, dan Jalan Lamadukelleng. Penelitian ini bertujuan menganalisis kinerja Manajemen Lalu Lintas Baru ini terhadap perbaikan kondisi lalu lintas di kawasan Losari. Hasil studi ini menunjukkan bahwa penerapan Manajemen Lalu Lintas Baru di kawasan Losari berhasil memperbaiki kondisi lalu lintas di kawasan tersebut. Melalui skema manajemen lalu lintas yang baru ini, ketiga ruas jalan yang diamati mempunyai tingkat pelayanan A.
\end{abstract}

Kata-kata kunci: kemacetan lalu lintas, manajemen lalu lintas, tingkat pelayanan

\section{PENDAHULUAN}

Kota Makassar merupakan salah satu kota metropolitan di Indonesia yang mengalami kemacetan parah di beberapa ruas jalan. Sebagai kota metropolitan, pertumbuhan ekonomi Kota Makassar mencapai 8,23\%, yang mengalahkan pertumbuhan ekonomi Provinsi Sulawesi Selatan, yang hanya sebesar 7,07\% (Badan Pusat Statistik Kota Makassar, 2018). Karena itu, Kota Makassar menjadi penyangga utama perekonomian di Provinsi Sulawesi Selatan. 
Seiring dengan pertumbuhan ekonomi, jumlah kendaraan bermotor di Kota Makassar juga mengalami kenaikan, berkisar 7\% setiap tahunnya. Pada tahun 2016 tercatat 1.425 .151 unit atau bertambah 87.009 unit dibandingkan dengan jumlah pada tahun 2015. Pada tahun 2014, jumlah kendaraan bermotor masih 1.252.755 unit, yang berarti dalam 2 tahun tercatat penambahan 172.395 unit. Laju pertumbuhan kendaraan didominasi oleh kendaraan roda 2, yang sejak 2014 menembus angka satu juta, yaitu 1.128.809 unit (Sistem Administrasi Manunggal Satu Atap (SAMSAT) Kota Makassar, 2018).

Pertumbuhan kendaraan yang tinggi, yang tidak diimbangi dengan penambahan jaringan jalan akan memperparah kemacetan di Kota Makassar. Kemacetan juga disebabkan oleh kondisi jalan dan kondisi sistem prasarana transportasi yang tidak berfungsi secara optimal, karena adanya kegiatan-kegiatan nonformal yang menyebabkan penurunan kapasitas jalan. Sebagai contoh adalah penggunaan trotoar oleh pedagang kaki lima atau kegiatan parkir di badan jalan, yang berakibat pada makin parahnya tingkat kemacetan (Bau dan Dulbahri, 2005). Selain itu, ketidaktertiban pengendara kendaraan bermotor dan tata ruang yang semrawut semakin memperparah kemacetan. Hampir di setiap sudut kota terjadi penumpukan kendaraan, apalagi pada jam-jam sibuk, dan situasi ini terjadi di beberapa ruas jalan, termasuk di ruas-ruas jalan yang berada di kawasan Losari.

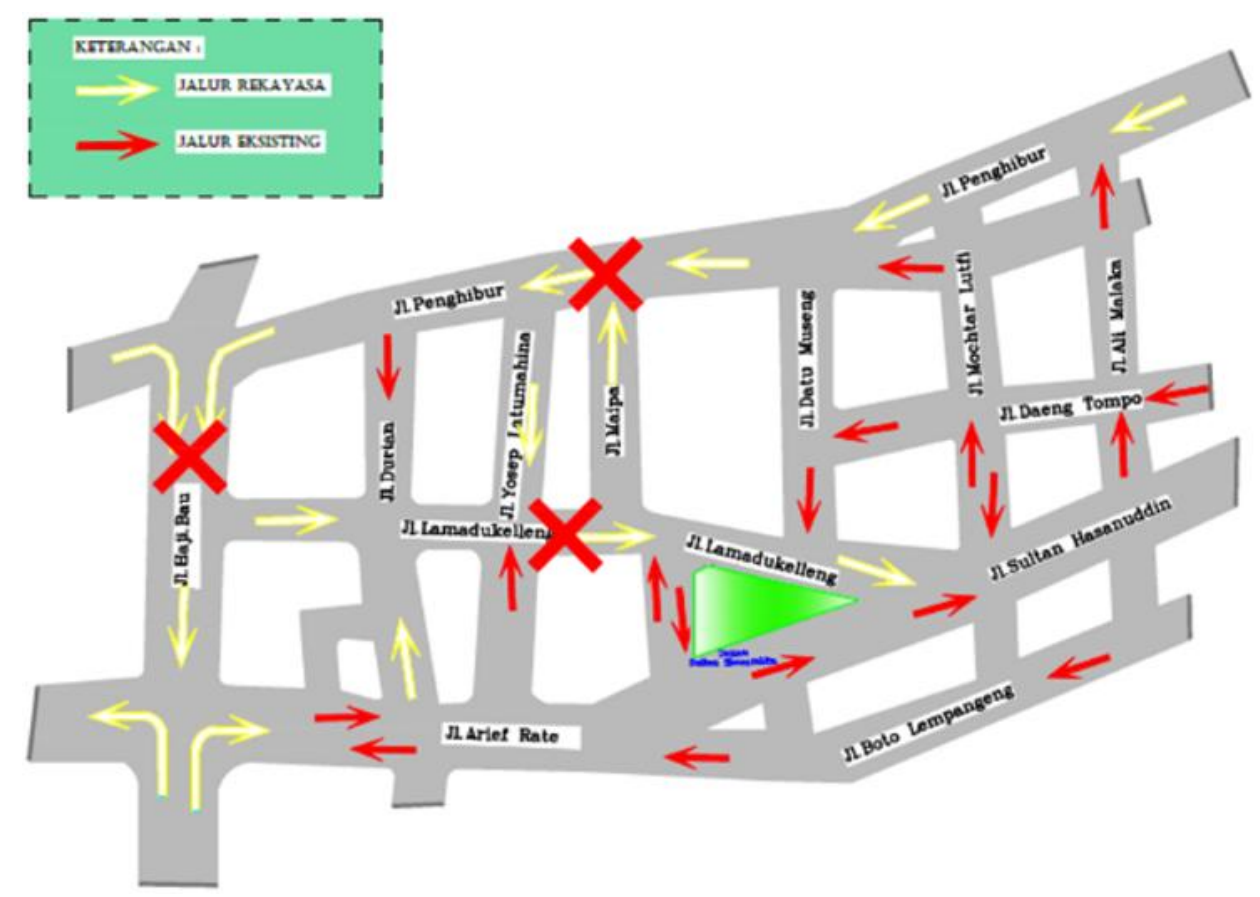

Gambar 1 Lokasi Penelitian

Pemerintah Kota Makassar telah berupaya mengatasi kemacetan lalu lintas di kawasan Losari. Salah satunya adalah dengan melakukan manajemen lalu lintas, yaitu pemberlakuan sistem satu arah yang telah berlangsung lama. Tetapi sistem satu arah tersebut dianggap kurang efektif, sehingga pada tahun 2019 dilakukan perubahan arah sistem satu arah di beberapa ruas jalan yang diistilahkan Manajemen Lalu Lintas Baru (New Traffic Management). Manajemen Lalu Lintas Baru ini merupakan perubahan arah aliran kendaraan 
di beberapa ruas jalan di kawasan Losari, dari yang semula arah selatan ke utara di Jalan Penghibur menjadi arah utara ke selatan, arah aliran kendaraan dari timur ke arah barat menjadi arah barat ke arah timur pada ruas Jalan Haji Bau, serta perubahan arah utara ke selatan menjadi selatan ke utara pada ruas Jalan Lamadukelleng. Ketiga ruas jalan tersebut yang menjadi obyek penelitian ini (lihat Gambar 1).

Studi ini bertujuan menganalisis kinerja Manajemen Lalu Lintas Baru di kawasan Losari Kota Makassar melalui metode analisis statistika deskriptif (Sugiyono, 2018), karena dilakukan hanya untuk mengetahui keberadaan variabel mandiri. Karena itu, pada penelitian ini tidak dilakukan perbandingan terhadap variabel-variabel yang diamati.

Perhitungan indikator kinerja jalan yang diamati didasarkan pada Manual Kapasitas Jalan Indonesia (MKJI) 1997, yang meliputi volume atau arus lalu lintas, kapasitas, derajat kejenuhan, kecepatan arus bebas, serta kecepatan dan waktu tempuh rata-rata. Sedangkan penentuan tingkat pelayanan jalan didasarkan pada Peraturan Menteri Perhubungan Nomor 14 Tahun 2006, tentang Manajemen dan Rekayasa Lalu Lintas di Jalan.

Penelitian ini merupakan penelitian kuantitatif deskriptif, yang membahas kinerja Manajemen Lalu Lintas Baru di Kawasan Losari, Kota Makassar. Data primer diperoleh dari observasi langsung di lapangan, sedangkan data sekunder diambil berdasarkan nilai-nilai yang menjadi ketetapan pada MKJI 1997. Penelitian dilakukan pada 3 ruas jalan di Kawasan Losari, yaitu ruas Jalan Penghibur, ruas Jalan Haji Bau, dan ruas Jalan Lamadukelleng. Pengumpulan data dilakukan pada Bulan Mei sampai Bulan Juli 2019, selama 4 hari, yaitu Hari Senin dan Hari Jumat, yang mewakili hari kerja, serta Hari Sabtu dan Hari Minggu, yang mewakili hari libur.

\section{HASIL DAN PEMBAHASAN}

\section{Volume Lalu Lintas}

Pencatatan untuk tipe kendaraan dikategorikan ke dalam 3 jenis, yaitu sepeda motor (MC), kendaraan ringan (LV), dan kendaraan berat (HV). Data volume lalu lintas untuk masing-masing ruas jalan dsajikan pada Tabel 1, Tabel 2, dan Tabel 3. Terlihat bahwa volume lalu lintas rata-rata di Jalan Penghibur sebesar 1.707,3 smp/jam, di Jalan Haji Bau sebesar 1.437,2 smp/jam, dan di Jalan Lamadukelleng sebesar 1.077 smp/jam.

Tabel 1 Volume Lalu Lintas di Jalan Penghibur

\begin{tabular}{|c|c|c|c|c|c|}
\hline \multirow[b]{2}{*}{ No. } & \multirow[b]{2}{*}{ Waktu } & \multicolumn{3}{|c|}{ Kendaraan } & \multirow[b]{2}{*}{$\begin{array}{l}\text { Volume } \\
\text { (smp/jam) }\end{array}$} \\
\hline & & $\begin{array}{c}\text { MC } \\
\text { (smp/jam) }\end{array}$ & $\begin{array}{c}\mathrm{LV} \\
\text { (smp/jam) }\end{array}$ & $\begin{array}{c}\mathrm{HV} \\
\text { (smp/jam) }\end{array}$ & \\
\hline 1 & Senin & 494,8 & $1.175,5$ & 40,3 & $1.710,6$ \\
\hline 2 & Jumat & 519 & 781 & 29,9 & $1.329,9$ \\
\hline 3 & Sabtu & 510,6 & 1.429 & 8,45 & $1.948,1$ \\
\hline 4 & Minggu & 534,6 & 1.297 & 9,1 & $1.840,7$ \\
\hline & Total: & 2.059 & $4.682,5$ & 87,8 & $6.829,3$ \\
\hline & Rata-Rata: & 514,8 & 1170,6 & 21,9 & $1.707,3$ \\
\hline
\end{tabular}


Tabel 2 Volume Lalu Lintas Jalan Haji Bau

\begin{tabular}{|c|c|c|c|c|c|}
\hline \multirow[b]{2}{*}{ No. } & \multirow[b]{2}{*}{ Waktu } & \multicolumn{3}{|c|}{ Kendaraan } & \multirow[b]{2}{*}{$\begin{array}{l}\text { Volume } \\
\text { (smp/jam) }\end{array}$} \\
\hline & & $\begin{array}{c}\mathrm{MC} \\
\text { (smp/jam) }\end{array}$ & $\begin{array}{c}\mathrm{LV} \\
\text { (smp/jam) }\end{array}$ & $\begin{array}{c}\mathrm{HV} \\
\text { (smp/jam) }\end{array}$ & \\
\hline 1 & Senin & 520,6 & 1.134 & 39,65 & $1.694,3$ \\
\hline 2 & Jumat & 217,6 & 557,5 & 657,2 & $1.432,3$ \\
\hline 3 & Sabtu & 288 & 422,5 & 518,1 & $1.228,6$ \\
\hline 4 & Minggu & 210 & $1.141,5$ & 42,3 & $1.393,8$ \\
\hline & Total: & $1.236,2$ & $3.255,5$ & $1.257,1$ & $5.748,8$ \\
\hline & Rata-Rata: & 309,1 & 813,9 & 314,3 & $1.437,2$ \\
\hline
\end{tabular}

Tabel 3 Volume Lalu Lintas di Jalan Lamadukelleng

\begin{tabular}{|c|c|c|c|c|c|}
\hline \multirow[b]{2}{*}{ No. } & \multirow[b]{2}{*}{ Waktu } & \multicolumn{3}{|c|}{ Kendaraan } & \multirow[b]{2}{*}{$\begin{array}{l}\text { Volume } \\
\text { (smp/jam) }\end{array}$} \\
\hline & & $\begin{array}{c}\text { MC } \\
\text { (smp/jam) }\end{array}$ & $\begin{array}{c}\mathrm{LV} \\
\text { (smp/jam) }\end{array}$ & $\begin{array}{c}\mathrm{HV} \\
\text { (smp/jam) }\end{array}$ & \\
\hline 1 & Senin & 494 & 627,5 & 30,6 & $1.152,1$ \\
\hline 2 & Jumat & 525,6 & 538,5 & 17,6 & $1.081,7$ \\
\hline 3 & Sabtu & 574,4 & 326 & 7,8 & 908,2 \\
\hline 4 & Minggu & 407,8 & 744,5 & 13,7 & 1.166 \\
\hline & Total: & $2.001,8$ & $2.236,5$ & 69,6 & $4.307,9$ \\
\hline & Rata-Rata: & 500,5 & 559,1 & 17,4 & 1.077 \\
\hline
\end{tabular}

\section{Kapasitas}

Kapasitas adalah jumlah arus lalu lintas (stabil) maksimum yang dapat dipertahankan pada kondisi tertentu, yang meliputi geometri, distribusi arah dan komposisi lalu lintas, serta faktor lingkungan, dengan satuan smp/jam. Perhitungan kapasitas ruas jalan dilakukan dengan berpedoman pada proses perhitungan yang ada pada MKJI Tahun 1997. Formula untuk menghitung kapasitas adalah sebagai berikut:

$$
\mathrm{C}=\mathrm{C}_{0} \times \mathrm{FC}_{\mathrm{W}} \times \mathrm{FC}_{\mathrm{SP}} \times \mathrm{FC}_{\mathrm{SF}} \times \mathrm{FC}_{\mathrm{CS}}
$$

dengan:

$\mathrm{C} \quad=$ kapasitas (smp/jam);

$\mathrm{C}_{0} \quad=$ kapasitas dasar ( $\left.\mathrm{smp} / \mathrm{jam}\right)$;

$\mathrm{FC}_{\mathrm{W}}=$ faktor penyesuaian lebar jalur lalu lintas;

$\mathrm{FC}_{\mathrm{SP}}=$ faktor penyesuaian pemisah arah;

$\mathrm{FC}_{\mathrm{SF}}=$ faktor penyesuaian hambatan samping; dan

$\mathrm{FC}_{\mathrm{CS}}=$ faktor penyesuaian ukuran kota.

Ketiga ruas jalan yang diamati merupakan jalan 2 lajur tak terbagi. Menurut MKJI, kapasitas dasar $\left(\mathrm{C}_{0}\right)$ masing-masing ruas jalan tersebut adalah $2.900 \mathrm{smp} / \mathrm{jam}$.

Untuk menentukan faktor penyesuaian lebar jalur lalu lintas $\left(\mathrm{FC}_{\mathrm{W}}\right)$, harus diukur lebar jalan yang ada. Data lebar jalan dan faktor penyesuaian lebar jalur lalu lintas untuk masing-masing ruas jalan yang diamati dapat dilihat pada Tabel 4. 
Tabel 4 Faktor Penyesuaian Lebar Jalur Lalu Lintas

\begin{tabular}{lccc}
\hline \multicolumn{1}{c}{ Nama Jalan } & Tipe Jalan & Lebar $(\mathrm{m})$ & $\mathrm{FC}_{\mathrm{W}}$ \\
\hline Jalan Penghibur & Dua jalur tak terbagi & 13,7 & 1,34 \\
Jalan Haji Bau & Dua jalur tak terbagi & 8,0 & 1,14 \\
Jalan Lamadukelleng & Dua jalur tak terbagi & 8,5 & 0,87 \\
\hline
\end{tabular}

Dari pengamatan di lapangan diketahui bahwa ketiga ruas jalan, yaitu Jalan Penghibur, Jalan Haji Bau, dan Jalan Lamadukelleng tidak menggunakan median. Untuk pergerakan lalu lintas 1 arah, faktor penyesuaian pemisah arah (FCsp) untuk masing-masing jalan ini adalah 1,00 .

Untuk menentukan faktor penyesuaian hambatan samping ( $\left.\mathrm{FC}_{\mathrm{SF}}\right)$ dilakukan pengamatan lapangan di ketiga ruas jalan yang dikaji. Dari pengamatan lapangan tersebut diperoleh jumlah kejadian berbobot untuk Jalan Penghibur, Jalan Haji Bau, dan Jalan Lamadukelleng, seperti yang disajikan pada Tabel 5 hingga Tabel 7. Penentuan FC $\mathrm{SF}_{\mathrm{SF}}$ dapat dilihat pada Tabel 8.

Tabel 5 Hasil Perhitungan Bobot Hambatan Samping di Jalan Penghibur

\begin{tabular}{lccccccc}
\hline & & \multicolumn{7}{c}{ Frekuensi Kejadian Berbobot } \\
\cline { 3 - 8 } \multicolumn{1}{c}{ Tipe Kejadian } & Faktor & $08.00-$ & $09.00-$ & $12.00-$ & $13.00-$ & $15.00-$ & $16.00-$ \\
& Bobot & 09.00 & 10.00 & 13.00 & 14.00 & 16.00 & 17.00 \\
\hline Pejalan Kaki & 0,50 & 13,67 & 7 & 14,25 & 17,88 & 22,13 & 60,25 \\
Kendaraan Parkir, Berhenti & 1,00 & 108,33 & 115,67 & 96,13 & 89,75 & 78,25 & 83,5 \\
Kendaraan Masuk dan Keluar & 0,70 & 24,83 & 26,5 & 52,63 & 44,5 & 42,75 & 41,38 \\
Kendaraan Lambat & 0,40 & 32,67 & 25,17 & 15,75 & 18,75 & 23,25 & 30 \\
\hline \multicolumn{1}{c}{ Jumlah: } & & 179,5 & 174,33 & 178,75 & 170,88 & 166,38 & 215,13 \\
\hline
\end{tabular}

Tabel 6 Hasil Perhitungan Bobot Hambatan Samping di Jalan Haji Bau

\begin{tabular}{lcrrrrcc}
\hline & & \multicolumn{7}{c}{ Frekuensi Kejadian Berbobot } \\
\cline { 3 - 8 } \multicolumn{1}{c}{ Tipe Kejadian } & Faktor & $08.00-$ & $09.00-$ & $12.00-$ & $13.00-$ & $15.00-$ & $16.00-$ \\
& Bobot & 09.00 & 10.00 & 13.00 & 14.00 & 16.00 & 17.00 \\
\hline Pejalan Kaki & 0,50 & 6,83 & 3,5 & 7,13 & 8,94 & 11,06 & 30,13 \\
Kendaraan Parkir, Berhenti & 1,00 & 108,33 & 115,67 & 96,13 & 89,75 & 78,25 & 83,5 \\
Kendaraan Masuk dan Keluar & 0,70 & 17,38 & 18,55 & 36,84 & 31,15 & 29,93 & 28,96 \\
Kendaraan Lambat & 0,40 & 13,07 & 10,07 & 6,3 & 7,5 & 9,3 & 12 \\
\hline \multicolumn{1}{c}{ Jumlah: } & & 145,62 & 147,78 & 146,39 & 137,34 & 128,54 & 154,59 \\
\hline
\end{tabular}

Tabel 7 Hasil Perhitungan Bobot Hambatan Samping di Jalan Lamadukelleng

\begin{tabular}{|c|c|c|c|c|c|c|c|}
\hline \multirow[b]{2}{*}{ Tipe Kejadian } & \multirow[b]{2}{*}{$\begin{array}{l}\text { Faktor } \\
\text { Bobot }\end{array}$} & \multicolumn{6}{|c|}{ Frekuensi Kejadian Berbobot } \\
\hline & & $\begin{array}{c}08.00- \\
09.00\end{array}$ & $\begin{array}{c}09.00 \\
10.00\end{array}$ & $\begin{array}{c}12.00- \\
13.00\end{array}$ & $\begin{array}{c}13.00- \\
14.00\end{array}$ & $\begin{array}{r}15.00 \\
16.00\end{array}$ & $\begin{array}{r}16.00 \\
17.00\end{array}$ \\
\hline Pejalan Kaki & 0,50 & 28,75 & 16,88 & 9,25 & 21,44 & 7,19 & 9,06 \\
\hline Kendaraan Parkir, Berhenti & 1,00 & 44,5 & 43,5 & 35,63 & 41,88 & 38,88 & 38,13 \\
\hline Kendaraan Masuk dan Keluar & 0,70 & 16,1 & 16,89 & 18,99 & 16,01 & 18,64 & 16,89 \\
\hline Kendaraan Lambat & 0,40 & 40,8 & 23,35 & 8,7 & 9,15 & 8 & 9,85 \\
\hline Jumlah: & & 130,15 & 100,61 & 72,56 & 88,48 & 72,7 & 73,93 \\
\hline
\end{tabular}


Tabel 8 Penentuan Faktor Penyesuaian Hambatan Samping

\begin{tabular}{lclc}
\hline \multicolumn{1}{c}{ Nama Jalan } & $\begin{array}{c}\text { Kelas Hambatan } \\
\text { Samping }\end{array}$ & \multicolumn{1}{c}{ Kriteria } & FC $_{\mathrm{SF}}$ \\
\hline Jalan Penghibur & $\mathrm{L}$ & Jarak rata-rata kereb ke penghalang $<0,5 \mathrm{~m}$ & 0,90 \\
Jalan Haji Bau & $\mathrm{L}$ & Jarak rata-rata kereb ke penghalang $<0,5 \mathrm{~m}$ & 0,90 \\
Jalan Lamadukelleng & $\mathrm{VL}$ & Lebar bahu efektif 1,0 m & 0,96 \\
\hline
\end{tabular}

Faktor penyesuaian ukuran kota dipengaruhi oleh populasi kota tempat ruas-ruas jalan yang diamati berada. Pada tahun 2018, jumlah penduduk Kota Makassar adalah 1.489.011 jiwa (BPS Kota Makassar, 2018), sehingga diperoleh nilai FC $_{C S}$ untuk ketiga ruas jalan yang diamati sebesar 1,00.

Dengan menggunakan data yang telah diperoleh dapat dihitung kapasitas Jalan Penghibur, Jalan Haji Bau, dan Jalan Lamadukelleng. Hasil perhitungan kapasitas ini dapat dilihat pada Tabel 9.

Tabel 9 Kapasitas Masing-Masing Ruas Jalan

\begin{tabular}{lcccccc}
\hline \multicolumn{1}{c}{ Nama Jalan } & $\begin{array}{c}\mathrm{C}_{0} \\
(\mathrm{smp} / \mathrm{jam})\end{array}$ & $\mathrm{FC}_{\mathrm{W}}$ & $\mathrm{FC}_{\mathrm{SP}}$ & $\mathrm{FC}_{\mathrm{SF}}$ & $\mathrm{FC}_{\mathrm{CS}}$ & $\begin{array}{c}\mathrm{C} \\
(\mathrm{smp} / \mathrm{jam})\end{array}$ \\
\hline Jalan Penghibur & 2.900 & 1,34 & 1,00 & 0,90 & 1,00 & 3.591 \\
Jalan Haji Bau & 2.900 & 1,14 & 1,00 & 0,90 & 1,00 & 3.173 \\
Jalan Lamadukelleng & 2.900 & 0,87 & 1,00 & 0,96 & 1,00 & 2.422 \\
\hline
\end{tabular}

\section{Derajat Kejenuhan}

Derajat Kejenuhan (DS), yang merupakan rasio antara volume lalu lintas di suatu ruas jalan terhadap kapasitas ruas jalan tersebut, dihitung dengan menggunakan volume lalu lintas dan nilai kapasitas jalan yang telah diperoleh. Nilai-nilai DS untuk ketiga ruas jalan yang diamati disajikan pada Tabel 10, Tabel 11, dan Tabel 12.

Tabel 10 Derajat Kejenuhan Jalan Pengibur

\begin{tabular}{lccc}
\hline \multicolumn{1}{c}{ Hari } & $\begin{array}{c}\text { Volume } \\
(\text { smp/jam })\end{array}$ & $\begin{array}{c}\text { Kapasitas } \\
(\text { smp/jam })\end{array}$ & $\begin{array}{c}\text { Derajat Kejenuhan } \\
(\mathrm{DS})\end{array}$ \\
\hline Senin & $1.710,6$ & 3.591 & 0,47 \\
Jumat & $1.329,9$ & 3.591 & 0,37 \\
Sabtu & $1.948,1$ & 3.591 & 0,54 \\
Minggu & $1.840,7$ & 3.591 & 0,51 \\
\hline Rata-Rata & $1.707,3$ & 3.591 & 0,47 \\
\hline
\end{tabular}

Tabel 11 Derajat Kejenuhan Jalan Haji Bau

\begin{tabular}{lccc}
\hline \multicolumn{1}{c}{ Hari } & $\begin{array}{c}\text { Volume } \\
(\text { smp/jam })\end{array}$ & $\begin{array}{c}\text { Kapasitas } \\
(\text { smp/jam })\end{array}$ & $\begin{array}{c}\text { Derajat Kejenuhan } \\
(\mathrm{DS})\end{array}$ \\
\hline Senin & $1.694,3$ & 3.173 & 0,53 \\
Jumat & $1.432,3$ & 3.173 & 0,45 \\
Sabtu & $1.228,6$ & 3.173 & 0,38 \\
Minggu & $1.393,8$ & 3.173 & 0,43 \\
\hline Rata-Rata & $1.437,2$ & 3.173 & 0,45 \\
\hline
\end{tabular}


Tabel 12 Derajat Kejenuhan Jalan Lamadukelleng

\begin{tabular}{lccc}
\hline \multicolumn{1}{c}{ Hari } & $\begin{array}{c}\text { Volume } \\
(\text { smp/jam })\end{array}$ & $\begin{array}{c}\text { Kapasitas } \\
(\text { smp/jam })\end{array}$ & $\begin{array}{c}\text { Derajat Kejenuhan } \\
(\mathrm{DS})\end{array}$ \\
\hline Senin & $1.152,1$ & 2.442 & 0,47 \\
Jumat & $1.081,7$ & 2.442 & 0,44 \\
Sabtu & 908,2 & 2.442 & 0,37 \\
Minggu & $1.166,0$ & 2.442 & 0,47 \\
\hline Rata-Rata & $1.077,0$ & 2.442 & 0,44 \\
\hline
\end{tabular}

\section{Kecepatan Arus Bebas}

Perhitungan kecepatan arus bebas dilakukan dengan berpedoman pada Manual Kapasitas Jalan Indonesia (MKJI, 1997). Formula untuk menghitung kecepatan arus bebas adalah sebagai berikut:

$$
\mathrm{FV}=\left(\mathrm{FV}_{\mathrm{O}}+\mathrm{FV}_{\mathrm{W}}\right) \times \mathrm{FFV}_{\mathrm{SF}} \times \mathrm{FVV}_{\mathrm{CS}}
$$

dengan:

$\mathrm{FV} \quad=$ Kecepatan arus bebas kendaraan ringan pada kondisi lapangan $(\mathrm{km} / \mathrm{jam})$;

$\mathrm{FV}_{\mathrm{O}}=$ Kecepatan arus bebas dasar kendaraan ringan pada jalan yang diamati $(\mathrm{km} / \mathrm{jam})$;

$\mathrm{FV}_{\mathrm{W}}=$ Penyesuaian kecepatan untuk lebar jalan $(\mathrm{km} / \mathrm{jam})$;

$\mathrm{FFV}_{\mathrm{SF}}=$ Faktor penyesuaian untuk hambatan samping dan lebar bahu atau jarak kerb penghalang; dan

$\mathrm{FFV}_{\mathrm{CS}}=$ Faktor penyesuaian kecepatan untuk ukuran kota

Perhtungan kecepatan arus bebas untuk setiap ruas jalan yang diamati dapat dilihat pada Tabel 13, Tabel 14, dan Tabel 15.

Tabel 13 Penentuan Kecepatan Arus Bebas di Jalan Penghibur

\begin{tabular}{|c|c|c|}
\hline Variabel & Kriteria & Nilai Variabel \\
\hline $\mathrm{FV}_{\mathrm{O}}(\mathrm{km} / \mathrm{jam})$ & Jalan 2 jalur tak terbagi & 55 \\
\hline $\mathrm{FV}_{\mathrm{W}}(\mathrm{km} / \mathrm{jam})$ & $\begin{array}{l}\text { Lebar badan jalan } 13,7 \mathrm{~m} \text { terdiri atas } 2 \text { lajur } 1 \text { jalur, sehingga } \\
\text { lebar jalur adalah } \mathrm{Wc}=11 \mathrm{~m}\end{array}$ & 7 \\
\hline $\mathrm{FFV}_{\mathrm{SF}}$ & $\begin{array}{l}\text { Jalan dengan kerb } 2 \text { lajur } 1 \text { arah, Kelas Hambatan Samping } \\
\text { L dan lebar bahu efektif } \leq 0,5 \mathrm{~m}\end{array}$ & 0,93 \\
\hline $\mathrm{FFV}_{\mathrm{CS}}$ & Jumlah penduduk Kota Makassar 1.489.011 jiwa & 1,0 \\
\hline & $\mathrm{FV}(\mathrm{km} / \mathrm{jam})$ & 57,66 \\
\hline
\end{tabular}

Tabel 14 Penentuan Kecepatan Arus Bebas di Jalan Haji Bau

\begin{tabular}{|c|c|c|}
\hline Variabel & Kriteria & Nilai Variabel \\
\hline $\mathrm{FV}_{\mathrm{O}}(\mathrm{km} / \mathrm{jam})$ & Jalan 2 jalur tak terbagi & 55 \\
\hline $\mathrm{FV}_{\mathrm{W}}(\mathrm{km} / \mathrm{jam})$ & $\begin{array}{l}\text { Lebar badan jalan } 11,5 \mathrm{~m} \text { terdiri atas } 2 \text { lajur } 1 \text { jalur, sehingga } \\
\text { lebar jalur adalah } \mathrm{Wc}=8 \mathrm{~m}\end{array}$ & 3 \\
\hline $\mathrm{FFV}_{\mathrm{SF}}$ & $\begin{array}{l}\text { Jalan dengan kerb } 2 \text { lajur } 1 \text { arah, Kelas Hambatan Samping } \\
\mathrm{L} \text { dan lebar bahu efektif } \leq 0,5 \mathrm{~m}\end{array}$ & 0,93 \\
\hline $\mathrm{FFV}_{\mathrm{CS}}$ & Jumlah penduduk Kota Makassar 1.489.011 jiwa & 1,0 \\
\hline & $\mathrm{FV}(\mathrm{km} / \mathrm{jam})$ & 53,94 \\
\hline
\end{tabular}


Tabel 14 Penentuan Kecepatan Arus Bebas di Jalan Lamadukelleng

\begin{tabular}{|c|c|c|}
\hline Variabel & Kriteria & Nilai Variabel \\
\hline $\mathrm{FV}_{\mathrm{O}}(\mathrm{km} / \mathrm{jam})$ & Jalan 2 jalur tak terbagi & 55 \\
\hline $\mathrm{FV}_{\mathrm{W}}(\mathrm{km} / \mathrm{jam})$ & $\begin{array}{l}\text { Lebar badan jalan } 8,5 \mathrm{~m} \text { terdiri atas } 2 \text { lajur } 1 \text { arah, sehingga } \\
\text { lebar jalur adalah } \mathrm{Wc}=6 \mathrm{~m}\end{array}$ & 3 \\
\hline $\mathrm{FFV}_{\mathrm{SF}}$ & $\begin{array}{l}\text { Jalan dengan kerb } 2 \text { lajur } 1 \text { arah, Kelas Hambatan Samping } \\
\text { VL dan lebar bahu efektif } \leq 0,5 \mathrm{~m}\end{array}$ & 0,98 \\
\hline $\mathrm{FFV}_{\mathrm{CS}}$ & Jumlah penduduk Kota Makassar 1.489.011 jiwa & 1,0 \\
\hline & $\mathrm{FV}(\mathrm{km} / \mathrm{jam})$ & 50,96 \\
\hline
\end{tabular}

\section{Kecepatan dan Waktu Tempuh}

Waktu tempuh rata-rata di suatu ruas jalan dengan kondisi lalu lintas rata-rata digunakan dengan menggunakan formula sebagai berikut:

$$
\mathrm{TT}=\mathrm{L} / \mathrm{V}
$$

dengan:

$\mathrm{TT}=$ waktu tempuh rata-rata kendaraan ringan sepanjang segmen (jam);

$\mathrm{L}=$ panjang segmen $(\mathrm{km})$; dan

$\mathrm{V}=$ kecepatan rata-rata ruang kendaraan ringan $(\mathrm{km} / \mathrm{jam})$.

Perhitungan waktu tempuh rata-rata di ruas Jalan Penghibur, Jalan Haji Bau, dan Jalan Lamadukelleng disajikan pada Tabel 15.

Tabel 15 Penentuan Waktu Tempuh

\begin{tabular}{lccl}
\hline \multicolumn{1}{c}{ Nama Jalan } & $\begin{array}{c}\text { Panjang Segmen } \\
(\mathrm{km})\end{array}$ & $\begin{array}{c}\text { Kecepatan } \\
(\mathrm{km} / \text { jam })\end{array}$ & \multicolumn{1}{c}{ Waktu Tempuh } \\
\hline Jalan Penghibur & 1,2 & 42 & 0,028 jam (2 menit 8 detik) \\
Jalan Haji Bau & 0,364 & 43 & 0,008 jam (48 detik) \\
Jalan Lamadukelleng & 0,800 & 43 & 0,019 jam (1 menit 14 detik) \\
\hline
\end{tabular}

\section{Tingkat Pelayanan}

Tingkat pelayanan (Level of Servis, LOS) menyatakan tingkat kualitas lalu lintas yang sesungguhnya terjadi. Tingkat ini dinilai oleh pengemudi atau penumpang berdasarkan tingkat kemudahan dan kenyamanan mengemudi. Tingkat pelayanan di jalan-jalan yang diamati disajikan pada Tabel 16.

Tabel 16 Tingkat Pelayanan Jalan

\begin{tabular}{lccccc}
\hline \multicolumn{1}{c}{ Nama Jalan } & $\begin{array}{c}\text { Kondisi } \\
\text { Lalu Lintas }\end{array}$ & $\begin{array}{c}\text { Volume } \\
\text { Lalu Lintas }\end{array}$ & $\begin{array}{c}\text { Manuver } \\
\text { Pengemudi }\end{array}$ & $\begin{array}{c}\text { DS } \\
\text { Rata-Rata }\end{array}$ & $\begin{array}{c}\text { Tingkat } \\
\text { Pelayanan } \\
\text { (LOS) }\end{array}$ \\
\hline Jalan Penghibur & Bebas hambatan & Rendah & Tanpa tundaan & 0,47 & A \\
Jalan Haji Bau & Bebas hambatan & Rendah & Tanpa tundaan & 0,45 & A \\
Jalan Lamadukelleng & Bebas hambatan & Rendah & Tanpa tundaan & 0,44 & A \\
\hline
\end{tabular}




\section{PEMBAHASAN}

Berdasarkan hasil perhitungan, diperoleh hasil kinerja Manajemen Lalu Lintas Baru di kawasan Losari, Kota Makassar. Untuk ketiga ruas jalan yang diamati, Derajat Kejenuhan Rata-Rata di ketiga ruas jalan tersebut berkisar antara 0,44 hingga 0,47.

Pada hari-hari pengamatan, yaitu Senin, Jumat, Sabtu, dan Minggu, kondisi aliran lalu lintas umumnya terjadi dengan tanpa hambatan dan volume lalu lintas masuk pada kategori rendah. Pada kondisi ini pengemudi dapat menjaga kecepatannya tanpa mengalami tundaan.

Dengan derajat kejenuhan (DS) di masing-masing jalan yang rendah dan pengemudi tidak mengalami tundaan, tingkat pelayanan di Jalan Penghibur, Jalan Haji Bau, dan Jalan Lamadukelleng berada pada kategori A. Dengan demikian Manajemen Lalu Lintas Baru di kawasan Losari, Kota Makassar berhasil memperbaiki kondisi lalu lintas di kawasan tersebut.

\section{KESIMPULAN}

Penelitian ini dilakukan untuk menentukan dampak perubahan manajemen lalu lintas di kawasan Losari, Kota Makassar. Untuk itu, dilakukan pengamatan terhadap 3 ruas jalan di kawasan tersebut, yaitu Jalan Penghibur, Jalan Haji Bau, dan Jalan Lamadukelleng.

Jalan Penghibur mempunyai kapasitas jalan sebesar $3.591 \mathrm{smp} / \mathrm{jam}$ dan volume lalu lintas di jalan ini relatif rendah, sehingga pengemudi dapat menjaga kecepatan tanpa tundaan. Dengan derajat kejenuhan di jalan ini sebesar 0,47, tingkat pelayanan Jalan Penghibur berada pada Kategori A.

Jalan Haji Bau mempunyai kapasitas jalan sebesar $3.173 \mathrm{smp} / \mathrm{jam}$ dan volume lalu lintas yang termasuk rendah. Di jalan ini pengemudi dapat menjaga kecepatan kendaraannya tanpa mengalami tundaan. Nilai derajat kejenuhan di ruas jalan ini adalah 0,45 dan tingkat pelayanannya berada pada Kategori A.

Kondisi lalu lintas di ruas jalan yang ketiga, yaitu Jalan Lamadukelleng, serupa dengan kondisi lalu lintas di Jalan Penghibur dan di Jalan Haji Bau. Kapasitas jalan ini adalah $2.422 \mathrm{smp} / \mathrm{jam}$ dan volume lalu lintas yang ada relatif rendah, sehingga derajat kejenuhan di Jalan Lamadukelleng juga rendah, yaitu bernilai 0,44. Dengan kondisi ini, tingkat pelayanan Jalan Lamadukelleng juga berada pada Kategori A.

Berdasarkan hasil yang diperoleh, Manajemen Lalu Lintas Baru di kawasan Losari berhasil memperbaiki kondisi lalu lintas di kawasan tersebut. Ruas-ruas jalan yang diamati mempunyai tingkat pelayanan A, yang berarti bahwa Manajemen Lalu Lintas Baru yang diimplementasikan berhasil mengurangi potensi terjadinya kemacetan lalu lintas di kawasan tersebut. 


\section{DAFTAR PUSTAKA}

Badan Pusat Statistik Kota Makassar. 2018. Makassar dalam Angka. Makassar.

Bau, Q.D. dan Dulbahri, S. 2005. Penggunaan Citra Satelit Quickbird dan Sistem Informasi Geografis untuk Manajemen Lalu Lintas di Kota Yogyakarta. Tesis tidak diterbitkan. Yogyakarta: Program Magister, Universitas Gadjah Mada.

Direktorat Jenderal Bina Marga Departemen Pekerjaan Umum. 1997. Manual Kapasitas Jalan Indonesia (MKJI). Jakarta.

Pemerintah Republik Indonesia. 2006. Peraturan Menteri Perhubungan Nomor KM 14 Tahun 2006 tentang Manajemen dan Rekayasa Lalu Lintas di Jalan. Jakarta.

Sistem Administrasi Manunggal Satu Atap (SAMSAT) Kota Makassar. 2018. Jumlah Kendaraan Bermotor di Kota Makassar. Makassar.

Sugiyono. 2018. Metode Penelitian Pendidikan (Pendekatan Kuantitatif, Kualitatif, dan $R$ \& D). Bandung: Alfabeta. 